\title{
Triiodothyronine Measurement
}

National Cancer Institute

\section{Source}

National Cancer Institute. Triiodothyronine Measurement. NCI Thesaurus. Code C74747.

The determination of the amount of free and bound triiodothyronine present in a sample. 